\title{
Writing Genealogies: an exploration of Foucault's strategies for doing research
}

\author{
MAR IA TAMBOUKOU
}

\section{'Meeting' Foucault}

Like many people of my generation, when I was young I thought that the world needed dramatic changes and that I should do something about it. After spending several years actively involved in various off-mainstream political and feminist groups, I found myself trapped in an impasse of both theory and practice. It was the early 1980s in Greece; Europe was changing, the world was changing and theories seemed insufficient to account for what was happening. In the early 1990s I decided Lo leave Greece and escape to London. Jn my attempt to make a new start, I became interested in politics once more, but this time it was definitely politics with a small 'p'. It was then that I 'met' Foucault and had the idea of focusing my research on his work. Foucault's work came as an inspiration in a period when all political theory seemed dry to me and when political activity was no longer on the agenda. I think that my interest in Foucault coincided with a critical period in my life, when, dislocating myself from familiar spaces and places, 1 had felt the need to experiment with new modes of thinking and perhaps with new modes of being.

J n following Foucault, I think that I have become passionately interested in a wider shift in the European intellectual landscape: the return of ethics as a primary issue in the philosophical agenda, after so many years of the primary position of politics. I think that far from abandoning politics, this shift has been working towards redefining the subject(s) of politics and the very notion of P/politics itself. Following Foucault's intellectual paths, and especially his suggestion for writing genealogies, turned out to be an exciting adventure. There were a lot of things to be discovered. Foucault had used the term 'genealogy' to describe his work, but he insisted on not following any certain method ology to do that. On the contrary he was against all closed types of methodologies and instead he was continually slipping away from being committed to any of them. His intellectual work has been rather a move to go 'beyond' any existing theories and/or methodologies, yet he kept on referring again and again lo his works as genealogies. This paper is therefore focusing on the very ontology of the Foucauldian genealogy, being aware of 1 .he vanity of any attempt to frame the Foucauldian genealogy as a closed method for research, but at the same time acknowledging the need to map the 
Foucauldian genealogy in a cartography of contemporary problematics upon social and historical research. Therefore:

\section{What is Genealogy?}

In trying to work out this question, I think I should make clear that this paper is not attempting to open new directions in the philosophical and /or epistemological debate on Foucault's theories. Drawing on inufluential theorisations of the Foucauldian methodology lwill attempt to bring together those critical pieces that illuminate the dark tunnel of the genealogical method and make it 'usable'. Why and how to use genealogy as a critical tool is what I want to illustrate, but to do this I cannot help reflecting on, first of all, the ontology of the method. Therefore, what is genealogy?

Foucault has written lovely histories. Although tempting, however, Foucauldian histories have been highly interrogated. Foucault himself has written:

I am fully aware that I have never written anything other than fictions. For all that I would not want co say that they were outside the truth. It seems plausible to me to make fiction s work within truth, to introduce truth effects with a fictional discourse, and in some way to make discourse arouse, 'fabricate' something which does not yet exist, thus to fiction something. One 'fictions' history starting from a political reality that renders it true, one 'fictions' a politics that does not yet exist starting from a historical truth. (Foucault, cited in Dreyfus \& Rabinow, 1982, p. 204)

Against what are seen as traditional types of history, Foucault has proposed the Nietzschean theme of genealogy. This is what he calls the form of his reflection on the nature and development of modern power. A key Nictzschean insight for Foucault is that truth can not be separated from the procedures of its production. The philosopher's task is therefore to criticise, diagnose and demythologise 'truth phenomena'. Consequently genealogy is concerned with the processes, procedures and apparatuses by which truth and knowledge are produced, in what Foucault calls the discursive regime of the modern era. Instead of asking in which kinds of discourse we are entitled to believe, Foucault's genealogies pose the question of which kinds of practices tied to which kinds of external condition s determine the different knowledges in which we ourselves figure.

Drawing on the Enlightenment suggestion of 'emancipation from self-imposed immaturity' (cited in Rajchman, 1985, p. 56) the Foucauldian genealogy reflects on the present of philosophy as well as the philosopher's self-positioning and active intervention within thjs present:

- What is happening now?

- What is this 'now' within which all of us find ourselves?

According to Foucault these questions of the Aeflarung or of reason have been a central theme of philosophy from Kant to our own day. It is within the tradition of this form of philosophical thinking from Hegel through Nietzsche and Max Weber to the Frankfurt school that Foucault situates himself and his inquiries. 'What is it in the present that produces meaning for philosophical reflection?' (Foucault, in Kritzm an Laurence, 1988, p. 87). Like Kant, Foucault sees the present as a process that embodies thought, knowledge and philosophy. In reframing the Kantian questions, however, Foucault follows different trails to explore them. 
Discussing the Enlightenment roots of Foucault's genealogical project, Dreyfus and Rabinow (1982, p. 122) have written, 'Analytics today must find a way of taking seriously the problems and conceptual needs of the past, but not the solutions and conclusions based on them.' Jane Flax has also pointed out that the Enlightenment poses an important series of questions 'that still have value apart from their contaminated answers' (Flax, 1990, p. 236).

In examining the very Kantian concept of the present, Foucault introduces scepticism about universalist dogmas of truth, objectivity and pure scientific reason, and interrogates the supposed interconnections between reason, knowledge, progress, freedom and ethical action. Within this problematic, Foucault also attempts to sec differently the role of the t1linking subject, by first of all recognising the historical dimension of all human reality.

In elaborating new answers to Kantian questions, Foucault moves to an analysis of the different discursive and non-discursive ways in which the subject emerges in history. Genealogy conceives human reality as an effect of the interweaving of certain historical and cultural practices, which it sets out to trace and explore. Instead of seeing history as a continuous development of an ideal schema, genealogy is oriented lo discontinuities. Throughout the genealogical exploration there are frequent disruptions, uneven and haphazard processes of dispersion, that mil into question the supposed linear evolution of history. In this context of reversal, our present is not theorised as the result of a meaningful development, but rather as an episode, a result of struggle and relations of force and domination. Genealogy is the history of such fights, their deep strategies, and the ways that interconnect them. Foucault has argued ${ }^{1}$ that within relations of power, individuals and groups can find space to resist domination, exercise freedom and pursue their interests. He has thus drawn a significan t line of distinction between relations of power, as fields of games where freedom can be exercised and relations of domination, which needs resisting. While this distinction overturns arguments that his theorisation of power leaves no possibility of freedom, it is, however, a blurring distinction, which has created certain tensions in genealogical research that seeks to trace specific 'drawings' of this line. As it has been suggested, 'where do the various medical, psychiatric and carceral systems of surveillance and discipline, detailed in Discipline and Punish (Foucault, 1991) and elsewhere, stand in relation to that distinction?' (Maggi!, 1997, p. 66). As I will argue further on in this paper, such theoretical questions and philosophical aporias, raised by the use of genealogy, are more effectively worked out in the actual 'writing' of specific genealogies. Whether they are 'solved' or surpassed becomes a task and a challenge for the genealogist.

However, while genealogy focuses on the war of discourses and power relations, it does not slop there. By revealing discontinuities in the supposed continuous development of history, Foucault's genealogical project also implies a discontinuity in the present social formations. Genealogy is attempting to go further by tracing possible ways of thinking differently, instead of accepting and legitimating what arc already the 'truths' of our world. The aim is to provide a counter-memory that will help subjects recreate the historical and practical conditions of their present existence. This is the future to which genealogies aspire: opening possibilities for life, by separating us from 'ilie contingency that has made us what we are, the possibilily of no longer being, doing or thinking what we are, do, or tl1ink' (Mahon, 1992, p. 122).

\section{Searching Foucault}

There is today a vast literature related to the genealogical method as well as various 
readings of it, which, although not always outright contradictory, unfold the Foucauldian method in various dimensions. Despite their different perspectives, however, the analysts who have become attentive to Foucault's work stand on a common ground, the ground that according to Foucault 'is once more stirring under our feet' (Foucault, 1970, p. xxiv). Foucault's thinking strategies have emerged from 'the void left by man's disappearance' (Foucault, cited in Braidotti, 1991, p. 1), the instability that was created by the questioning of 'subjectivity' and 'rationality', Lhe discourses of the 'crisis' of modernity. As Foucault has mostly eloquently put it, 'this void docs not create a deficiency; it does not constitute a lacuna that must be filled. It is nothing more, and nothing else, than the unfolding of a space in which it is once more possible to think' (Foucault, cited in Braidotti, 1991, p. !). Foucault's work and the Literature that has revolved around it have therefore been unfolded in the spatial void of the crisis of modernity, along with other theories that have thematised the relation between language, subjectivity, social organisation and power. ${ }^{2}$

In their influential study Beyond Structuralism and Hermeneutics, Dreyfus and Rabinow (1982) trace the roots of Foucault's challenging ideas. What is remarkable in this study is the adoption of the term 'interpretive analytics' to capture the quintessence of Foucault's philosophical reflections. The study tries to follow Foucault's intellectual adventures: his initial reaction to the phenomenological methodologies he first dealt with in his studies; his detachment from the tradition of hermeneutic ontology of his earliest writings; his surpassing the influence of structuralism, which resulted in the 'bracketing' of archaeology and his tum to Nietzsche and genealogy. According to Dreyfus and Rabinow, situating Foucault in the map of philosophical t.11inking requires an under- standing of those approaches that have tried to surpass the conception of a mcallillg-giving transcendental subject, a key conception of phenomenology. As a response to phenomenology, the structuralist approach rejected both concepts, meaning and subject, arguing instead that t.llere arc objective laws governing all human activity, while hermeneutics kept meaning as a theme of philosophical investigation, situating it in the social practices and literary texts that it set out to explore. Dreyfus and Rabinow see Foucault's thought grappling with concepts arising from those three positions: phe-nomenology, structuralism and hermeneutics. Having abandoned the phenomenological strategy of defining the ontology of a transcendental meaning subject as well as the activities derived from 'him', Foucault was also critical of the structuralist elimination of all meaning and the project of seeing the world governed merely by rules, principles and structures. Finally he tried to avoid the continuous search for the deeper meaning of social practices and actors. Indeed he was concerned to demonstrate the cultural construction of the very notion of 'deep meaning' and he worked towards a method of analysis that would go beyond the above alternatives, while remaining aware of both their 'truths' and their flaws.

For the philosopher Gilles Deleuze, what is most fascinating in Foucault's work is the joy and gaiety of the writing itself, which reveals Foucault as a poetic philosopher, one who succeeds in deeply enchanting his audience. Deleuze notes that Foucault's work reveals three important dimensions of writing: 'to write is to struggle and resist, to write is to become, to write is to draw a map' (Deleuze, 1992, p. 44). Drawing on a self-description of Foucault himself made in an interview in Nouvelles Lilleraires, 17 March 1975, 'I am a cartographer', Deleuze sees genealogy as the act of drawing maps or a cartography of social diagrams. But what is a diagram? 'The diagram or abstract machine is the map of relations between forces, a map of destiny, or intensity, which 
proceeds by primary non-localisable relations and at every moment passes through every point, "or rather in every relation from one point to the other"' (Deleuze, 1992, p. 36).

Genealogy provides a functional microanalysis of power relations, operating on the smallest and most insignificant details. These are always local, but impossible to be localised for good, 'passing through every point', producing rather than repressing reality. Deleuze points out that in The Archaeology of Knowledge Foucault made the distinction between discursive and non-discursive formations but dealt exclusively I'lith the former. It was in the genealogical project of Discipline and Punish that Foucault's methodology made a decisive new step, abandoning the dualism of discursive and non-discursive fomlations and proposing the art of drawing a map or a cartography, to show how discursive and non-discursive formations coexist in various forms or correl lation, opposition or juxt aposition, pointed out by the cartographer. Deleuze notes that just as there are many diagrams responding to the various social fields in history, there arc also many diagrammatic functions, since 'every diagram is a spatio-temporal multiplicity' (Deleuze, 1992, p. 34). Every diagram is intersocial and constantly evolving, operating so as to produce a new kind of reality, 'by unmaking preceding realities and significations, constituting hundreds of points of emergence or creativity, unex-pected conjunction s or improbable continuum s' (Deleuze, 1992, p. 35). Genealogy is finally the exemplary means to illustrate the linking of theory and practice. Significantly, Discipline and Punish, the book that initiated the genealogical move in Foucault's work, was published in 1975, immediately after Foucault's involvement in GIP (Group of Information about Prisons) between 1971 and 1975.

John Rajchman (1985, 1 986, 199 1) offers a new and original interpretation of Foucault's project which he characterises as 'a modem practical philosophy'. He sees Foucault's genealogy as a Nietzschean rethinking of the relationship between freedom and truth and fully acknowled ges the critical dimension of the method. Unearthing the philosophical grounding of Foucault's historical method, Rachman defines Foucault's suggestion for 'doing history' as historical nominalism. Foucault's nominalist histories arc not dealing with things but with terms, categories and techniques that have come to be recognised as the great themes of history. Not denying their political perspective, Foucault's inquiries are therefore offering a historical answer to the philosophical question as to how such things were constituted, by employing four nominalist arguments.

First is the argument of dispersal, by which Foucault's analysis disrupts the supposed unity of reason, the subject and history. Second is the argument of reversal, shattering self-evidences of Western civilisation, like madness or the sovereignty of the slate. In Foucault's work the argument of reversal is celebrated in the notorious 'repressive hypothesis' by which Foucault calls into question the supposed historical repression of everything about and around sex which is itself interrogated as a category or concept. Third is the argument of critique which is at the heart of Foucault's project. Instead of criticising the past in terms of the present, the Foucau ldian histories criticise the present by reflecting upon the ways the discursive and institutional practices of the past still affect the constitution of the present. Fourth is the argument of singular enlightenment. Rajchman chooses the term 'scepticism' to describe Foucault's position in the line of philosophical tradition. He argues that as a sceptic Foucault refused to accept given dogmas and discourses of his time. For Rajchman, what Foucault aspires to is freedom from the restrictions that our history and culture have imposed on the way hum an beings und erstand the world and themselves. Freedom in the sense described above is therefore announced to be the ethical principle of Foucault's scepticism. 
As its title suggests, Mahon's (1992) study Foucault's Nietzschean Genealogy: truth, power, and the subject focuses on the Nietzschean aspect of Foucault's methodological ideas and the way they influenced the emergence of genealogy in the course of his researches. Mahon's fundamental argument is that genealogy should first be conceived as critique: 'as an attempt to reveal concrete, practical, and historical conditions of existence' (Mahon, 1992, p. 8) defining the target of his study to 'reveal what Foucault means by genealogical critique' (Mahon, 1992, p. 17). The study calls into question the previously discussed 'passage' of the philosopher from archaeology to genealogy, by highlighting Foucault's statement: 'No, no, no, ... no, no, I never stopped doing archaeology. I never stopped doing genealogy. Genealogy defines the target and the finality of the work and archaeology indicates the field witll which I deal to make a genealogy' (cited in Mah on, 1992, p. 2I2n).

In focusing on the micropolitical aspect of Foucault's genealogy, Todd May (1993) relates it to the work of critical theorists who, like Foucault, dealt with the analysis of rationality. Instead of arguing for or against rationality, Foucault proclaims that reason is a complex phenomenon that can neither be rejected nor accepted wholesale. Knowledge and truth exist but only as they apply to specific situations that the genealogical project sets out to explore in detail. This Foucauldian stance regarding rationality seems to inform May's study, which attempts to provide the epistemological grounds for Foucault's project as a way of articulating a response to criticisms of Foucault made by theorists of the late Frankfurt school. May sees the genealogical project a political critique of $1111 \mathrm{cropolitical}$ practices aiming to resist them. Resistance is immediately bound to freedom as it is unfolded in four different theses in Foucault's thought: first comes the understanding that freedom is not tautological with liberation, second the view th at freedom is a matter of concrete struggles for situated values, third a recognition of the historical contingency of freedom, and fourth the acceptance that tllerc is no necessary end point in the struggle for freedom.

In Critical and Effective Histories, Mitchell Dean (1994) examines Foucault's genealogies through the problematics that arise from the use of history in sociological research. Recognising the impossibility of 'ranking' Foucault either as a historian, or a philosopher or a sociologist or any combination of those three intellectual roles, Dean reflects on the ontology of genealogy as a 'history of the present' and traces the relations of archaeology and genealogy as a key step that reveals the potential of $111 \mathrm{e}$ genealogical method, to act as a critical and effective history. Addressing the theme of rationality, Dean excavates the ways in which Foucault was informed by, but at the same time engaged critically with the concept of rationalisation, the kernel of Max Weber's historical sociology. Dean identifies perspectivism as a shared notion in the method of both thinkers, while discerning at the same time their difference. In Weber's case, perspectivism is taken as merely subjective, while in Foucault's case perspectivism is rooted in the relation between forms of discourse, the historical struggle in which they arc immersed, the institutional practices to which they are linked, and the forms of au thority they presuppose' (Dean, 1994, p. 7 1). Dean further discusses in detail the critical dimension of Foucault's analytic practices, distinguishing the terms of critique and criticism in relation to the theoretical baggage the former carries with it. In Dean's analysis, 'unlike the Frankfurt notion of critique, criticism implies no necessary unity of its object, no necessary end of the criticism, and no necessary and universal grounds from which criticism is undertaken' (Dean, 1994, p. 119). Dean concludes that it is at this point that perspcctivism comes onto the stage, since once admitted it allows criticism to enter into the space of struggle of discourses. 
The bulk of literature that deals with the Foucauldian historiography primarily draws on the 1971 essay 'Nietzsche, genealogy, history', where Foucault elaborates the notion of genealogy which will turn out to be the cornerstone of his work on power. It is to an overview of this essay that I now turn.

Genealogy is gra, meticulous and patiently documentary. (Foucault, in Rabinow, 1986, p. 76)

Foucault has chosen colour aspects to initiate his theorising of the Nietzschean method. Nietzschean genealogy is gray as contrasted to English genealogy, which is blue, in the sense that, in searching the hum an interiority, it lacks specific directions and seems to be wandering about, as if one were looking 'into the blu e' (Mahon, 1992, p. 86). It is the colour of the bulk of documents, the 'cyclopean monuments' in Nietzsche's words (cited in Mahon, 1992, p. 87), that give Nietzschean genealogy its grayness. History appears omnipresent in the 'gray' genealogy, while there is only a low level psychologism to be found in the 'blue type' of genealogy. ${ }^{3}$ Wh at is significantly different between the two colours is therefore the historical sense that turns out to be the bedrock on which Nietzschean genealogy rests.

Genealogy retrieves an indispensable restraint: it must record the singularity of events outside of any monotonous finali ty; it must seek them in t1le most unpromising places, in what we tend to feel is without history--in sentiments, love, conscience, instincts; it must be sensitive to their recurrence not in order to trace the natural curve of their evolution, but to isolate the different scenes where they engaged in different roles. Finally genealogy must define even those instances when they are absent, the moment when they remain unrealized. (Foucault, in Rabinow, 1986, p. 76)

As opposed to grand historical events, the genealogical search renders itself attentive to details, many of them having remained unnoticed and unrecorded in the narratives of mainstream history. By rejecting the teleological view of history, genealogy celebrates the philosophy of the event. The way things are is just an event, a random result of the interweaving of relations of power and domination. Genealogy as a method of analysis searches in the maze of dispersed events to trace discontinuities, recurrences and play where traditional historiography sees continuous development, progress and seriousness. Therefore, Foucault sees genealogy as an 'eventalization', a method that can attribute different dimensions to the ways traditional historians have dealt with the notion of the event. Eventalization begins with the interrogation of certain evidences of our culture on how things should be: 'making visible a singularity at places where there is a temptation to invoke a historical constant, an immediate anthropological trait, or an obviousness which imposes itself uniformly on all' (Foucault, in Burchell et al., 1991, p. 76). This breach of self-evidences also requires a rethinking of the various power relations that at a certain historical moment decisively influenced the way things were socially and historically established. As Foucault notes, this rethinking reveals 'a sort of multiplication or pluralization of causes' (Foucault, in Burchell et al., 1991, p. 76). This means that the genealogist does not regard singularity as simply an isolated piece of dala to be added in his/her documents. The event under scrutiny is to be analysed within the matrix of discursive and non-discursive practices that have given rise to its existence. McNay (1992, p. 142) has commented that for Foucault genealogical historiography avoids the errors of hermeneuticism that are inherent in mainstream forms of historical analysis. 
As I have already pointed out, a starting point of genealogy is that historically there arc no final 'truths' about our nature or the norms our reason dictates to us and therefore there is no essential, natural or inevitable way of grouping or classifying people. In this line of analysis, the genealogist does not look beyond or behind historical practices to find a simple unity of meaning or function, or a changeless significance of ourselves and the world around us. The aim is rather to look more closely at the workings of those practices in which moral norms and truths about ourselves have been constructed. fnstead of going deep, looking for origins and hidden meanings, the analyst is working on the surface, constructing 'a polygon or rather a polyhedron' (Foucault, in Burchell et al., 199 1, p. 77) of various minor processes that surround the emergence of the event. What is to be remembered is the fact that the more the analysis breaks down practices, the easier it becomes to find out more about their interrelation, while this process can never have a final end. Genealogy introduces the problem of how by becoming constituted as subjects we come to be subjected within particular configurations. Therefore, what one should study in history are the anonymous deep configurations that determine the ways we are classified and grouped, the genealogy of the constitution of our 'politics'. Foucault concludes by noting that in this sense, eventalization leads to an increasing polymorphism realised first as a polymorphism of the related elements, second as a polymorphism of the actual relations and third as a polymorphism of the domains of reference (Foucault, in Burchell el al., 1991, p. 77). A Foucault has very clearly stated, 'I would like in short to resituate the production of true and false at the heart of historical analysis and political critique' (Foucault, in Burchell el al., 1991, p. 77).

Genealogy, consequently, requires patience and a knowledge of details, and it depends on a vast accumulation of source material. (Foucault, in Rabinow, 1986, p. 76)

Clearly, the objects of these rigorous analyses are socio-historical phenomena, as Foucault has pointed out in the above essay (Foucault, in Rabinow, 1986, p. 77). What remains unclear is the fundamental nature of the documents under scrutiny. Although the majority of them rest on the shelves of the Bibliotheque Nationale and the Bihliotheque $d u$ Saulchoir, where, according to his biographers, Foucault, a real 'archive-addict', spent a greal deal of his life;' there is something more vivid than pure archive material that animates Foucault's writings. It is well known that since the very beginning, Foucault's work attracted audiences much wider than the dryly academic. For the American James Miller (1993), one of Foucault's biographers, it is the philosophical life of the thinker, his active involvement in what he was actually searching and reflecting upon, that accounts for the freshness and timeliness of his themes and ideas. Foucault's 'documents' were also to be found in the asylums, within the political demonstrations occurring outside prisons, or in the baths of San Francisco. Artaud's theatrical plays, the literary work of Battaille, Blanchot's novels, a famous work of art such as las Meninas or an object such as a pipe could tum out to be objects of his inquiries. ${ }^{5}$ This polymorphous and diverse map of documents and sources leaves future genealogists with an important legacy: that of going on 'inventing' new sources and areas of research not yet thought of by the so-called humanist sciences, so as continually to rethink and call into question the given truths of our world.

Foucault conceives of genealogy as an analysis of descent and emergence and devotes a great deal of reflection upon these two terms, tracing their various uses and connotations in the Nietzschean texts.

Descent records the the objective of genealogy and is opposed to a pretended 
unification of the self. Instead of implying a search for origins, the analysis of descent traces the numberless beginnings not easily captured by the historian 's eye. As Paul Veyne has lucidly put it:

Foucault has only one thing to say to historians: 'You may continue to explain history as you have always done. But be careful: if you look very closely, if you peel away the banalities, you will notice that there is more to explain than you thought; there are crooked contours that you haven't spotted.' (Veyne, 1997, p. 156).

A genealogical analysis of descent does not attempt to reconstruct the past nor does it trace the effects of past events in the present. In the analysis of descC11t, the genealogist makes the effort to look directly at what people do, without taking anything for granted, witl10ut presupposing the existence of any goal, material cause or ideology. The rum is to strip away the veils that cover people's practices, by simply showing how they are, and where they come from, describing its complicated forms and exploring its countless historical transformations. As Paul Veyne has seen it, practice in Foucault's thought 'is not some mysterious agency, some substratum of history, some hidden engine; it is what people do (the word says just what it means)' (Veyne, 1997, p. 153).

Thus, the analysis of descent disturbs previ ous immobile statements, fragments of unified truths, and exposes tlle heterogeneity of previous consistencies. In the search for descmt it turns out that 'truth or being docs not lie at the root of what we know and what we are' (Foucault, in Rabi now, 1986, p. 81). This conception is important in establishing the role of genealogy as critique. As I have already noted, the critical dimension of gen ealogy has been pointed out by several commentators. Finally tile analysis of descent reveals the total inscription of history on the body and everything that touches and surrounds the body. As Foucault notes, 'Genealogy as an analysis of descent, is thus situated within the articulation of the body and history. Its task is to expose a body totally imprinted by history and the process of history's distinction of the body' (Foucault, in Rabinow, 1986, p. 83). Both French and English-speaking tlleorists have drawn our attention to the critical role played by the body in the genealogical method. ${ }^{6}$ However, it is in the feminist strand of Foucault scholarship that the importance attributed to the body in his thought is particularly underlined and discussed in detail. ${ }^{7}$

The analysis of emergence must delineate the deployment of various processes and power relations in various systems of subjection within which things appeared as events on the stage of history. Emergence is attempting to grasp the very 'moment of arising' in Foucault's words (Foucault, in Rabinow, 1986, p. 83), being aware that this is only an accidental moment, an episode, and not the ultimate point of a historical evolution. 'Emergence is thus the entry of forces' (Foucault, in Rabinow, 1986, p. 84), the charting of the battle of forces that resulted in a certain state of affairs. Since anything can just happen in such a battle, 'no one is responsible for an emergence, no one can glory in it, since it always occurs in the interstice' (Foucault, in Rabinow, 1986, p. 85). In his analysis of the notion of emergence, Foucault seeks to detach his method from the 'presentism' of historical studies, an approach that attempts to understand and interpret past events in terms of tile present. Foucault has very clearly stated that he is not interested in 'w liting a history of the past in term s of the present' (Foucault, 1991, p. 31). Commenting on Foucault's rejection of the error of 'presentism', Dreyfus and Rabinow (1982) relate it to 'finalism', an approach to history which discovers Lhe causal source of a present formation somewhere in the past and then traces the series of continuous causalities that are supposed to reach the present. Therefore, if the analysis of emergence 
is the answer to presentism, then the analysis of descent is the answer to finalism and Foucault's methodology has broken with both. Most historians now tend to agree that these are 'vices to be avoided' (Dreyfus \& Rabinow, 1982, p. 118). According to Dreyfus and Rabinow, in the analysis of emergence Foucault seems to get rid of the psychological baggage of Nietzsche, since he does not attribute causes and responsibilities to the tactics of individuals, but to strategies, plays of domination, and the struggle of forces (Foucault, in Dreyfus \& Rabinow, 1982, p. 109).

Genealogy, then, is the analysis of descent and emergence in the sense that these two notions are found in the work of Nietzsche and discussed in Foucault's influential essay. Foucault later elaborates in detail the relation between descent, emergence and traditional history. Setting aside Nietzsche's attacks against history, Foucault focuses on the concept of rustorical sense in Nietzsche, suggesting that 'the historical sense can become a privileged instrument of genealogy' once it is done with 'the certainty of absolutes' (Foucault, in Rabinow, 1986, p. 87). In considering the notion of historical sense in Nietzsche, Foucault rethinks the three Nietzschean modalities of traditional history, namely the monumental, antiquarian and clitical history (cited in Mahon, 1992, p. 97) to which genealogy returns not to follow, but to metamorphose them. This return rests upon three anti-Platonic themes, which Foucault deploys in detail.

First is the parodic, anti-realist theme as opposed to a 'remembering history', that offers subjects identities borrowed from the glorious past. Genealogy reveals the masquerade of past identities and uses them in a playful manner as if there were some carnival party in which it were participating, so that 'the veneration of monuments becomes parody' (Foucault, in Rabinow, 1986, p. 97). Second is the dissociative theme, disrupting supposed historical continuity and dissolving coherent identities the fragments of which were kept together within the masks: 'the respect for ancient continuities becomes systematic dissociation' (Foucault, in Rabinow, 1986, p. 97). Third is the sacrificial theme as directed against the knowing character of history and contesting the supposed neutrality and objectivity of the subject of knowledge: 'the critique of the injustices of the past by a truth held by men in the present becomes the destruction of the man who maintains knowledge by the injustice proper to the will lo knowledge' (Foucault in Rabinow, 1986, p. 97). As Foucault sees it, these three anti-Platonic themes that guide the return of genealogy to history, are constructive elements of countermemory, a totally new dimension that transforms traditional historiography into an effective history. By disturbing the legends of the past, genealogy as effective history opens up paths for its subjects to set out for new, improbable identities.

In the genealogist's journey back lo history a series of methodological questions emerge: when and how can history turn out to be effective? A history renders itself effective when it develops the ability to distinguish singularities, acknowledge differences, decentre man as the subject of historical becoming and shatter the certainties of our very existence. Effective history deals with events, 'shortens its vision lo those things nearest to it, ... studies what is closest, but so a to seize it al a distance' (Foucault, in Rabinow, 1986, p. 89). In such a light, Foucault has seen his project as an 'ontology of the present' (Foucault, cited in Dean, 1994, p. 50), revealing questions of enlightenment as its bedrock. A history of the present is, however, more interested in the future. Calling into question self-evidences of the present by exposing the various ways they were constructed in the past, such histories shatter certain stabilities and help us detach ourselves from our 'truths' and seek ahernative ways of existence. In order for such transgressions to occur, however, effective histories should also break with our current systems of rationalisation and show that there is no truth but truths, no reason but rationalities, no knowledge but 
knowledges of the ways people have come to understand themselves and the world. As Rajchman (1985) has commented, by using history to problematise the subject, Foucault raises the question of freedom, not as a normative category, but as a 'real' situation of being, our possibility of questioning ourselves and modifying the politics of our existence. $^{8}$

\section{Doing Genealogy: how?}

What I have tried to do so far is not a systematisation of Foucault's background and of his philosophical orientations. Such an attempt would be at odds with Foucault's own problematisation of theoretical and epistemological classifications. Moreover, it is widely known that in mainstream social and political theory, Foucault's work has been criticised for not employing recognisable methodologies, 'a non-historical historian, an anrihumanist human scientist, a counter-slructurali st structuralist' (cited in Dreyfus \& Rabinow, 1982, p. xiv), and he himself occasionally made statements that have been quoted over and over again to illustrate the void Foucault created in any philosophical, historical or sociological dictionary of his time and afterwards: 'I don't feel it is necessary to know exactly what I am. The main interest in life is to become someone else you were not in the beginning. If you knew when you began a book what you would say at the end, do you think you would have the courage to write it?' (Foucault, in Martin et al., 1988, p. 9).

What I have then tried to do is to follow some of the routes of Foucault's intellectual journeys as well as to grasp the meanings of some of the theorists who have dealt with his work. Jn focusing my attention on the emergence of genealogy as a set of methodological strategies for research, I have come to the conclusion that there is no way of truly understanding what genealogy is about, other than by concentrating on a genealogy per sc, analysing it in its minor details, reaching the most remote points of its network, revealing the hidden micro-mechanisms of its operation, grasping the most delicate aspects of its theorisation. This is the first stage that inevitably leads to the adventure of writing one's own genealogy. It is in the intermingling of these processes, understanding theory and practising theory that I have come to realise the importance of an incident Jana Sawicki rem embers from her 1983 meeting with Foucault at a seminar on 'technologies of the self at the University of Vermont: ' 1 told him that I had just finished writing a dissertation on his critique of humanism. Not surprisingly, he responded with some emba rassment and much seriousness. He suggested that I not spend energy talking about him and, instead do what he was doing, namely, write genealogies' (Sawicki, 1991, p. 15).

It is therefore to the stage of 'how to do a genealogy' that this paper now moves. In this context, let us see how Foucault's work of the 'meta-discursive ${ }^{19}$ period can serve as an open paradigm of what doing a genealogy involves.

Three domains of genealogy arc possible. First, a historical ontology of ourselves in relation to trutll through which we constitute ourselves as subjects of knowledge; second a historical ontology of ourselves in relation to a field of power through which we constitute ourselves as subjects acting on others; third, a historical ontology in relation to ethics through which we constitute ourselves as moral agents. (Foucault, in Rabinow, 1986, p. 351)

In sketching out the structure of his project Foucault has delineated the triangle of truthpower-subject in which his research is applied and his genealogies are deployed. 
Although these three genealogical domains often meet, inform, overlap and sometimes juxtapose or even contradict each other, they have been illustratively inscribed in Foucault's books. Each of these books marks a different genealogical era in his thought and the process of his analyses. In tracing 'the different ways in our culture that humans develop knowledge about themselves' (Foucault, in Martin et al., 1988, pp. 17 18), Foucault tried to unmask certain 'truth games' and relate them to specific practices, 'technologies that human beings used to understand themselves' (Foucault, in .Martin et al., 1988, p. 8). As a real cartographer (Deleuze, 1992) Foucault again maps out four domains of such technologies: first the technologies of production, second the technologies of sign systems, third the technologies of power, and fourth the technologies of the self. It is the first stage of this work that can be read in books such as The Birth of the Clinic, the Order of things and the Archaeology of Knowledge, where Foucault seeks to isolate the first set of technologies that 'permit us to produce, transform, or manipulate things' (Foucault, in Martin et al., 1988, p. 18). In works such as his inaugural lecture, widely known as The Order of Discourse, Foucault elaborates theoretically the second set of technologies 'which permit us to use signs, meanings, symbols, or significations' (Foucault, in Martin et al., 1988, p. 18). In these domains of technologies Foucault's analyses still rem ain heavily 'discourse oriented' although the institutional practices have begun lo emerge in the background. As Foucault dramatically pointed out in his inaugural lecture:

The institution replies: you should not be afraid of beginnings; we are all here in order to show you that discourse belongs to the order of laws, that we have long been looking after its appearance, that a place has been made ready for it, a place which honours it but disarms it; and that if discourse may sometimes have some power, nevertheless it is from us and us alone that il gets it (Foucault, in Young, 1981, p. 52)

The reassuring institution that appears to protect but al the same time direct or eliminate 'the order of discourse' flourishes, develops and is analysed to its minor details beh ind the Wcbelan 'iron cages'. These 'iron cages', however, are put in a different context and a different analytical course in Foucault's works that, like the world famous Discipline and Punish, focus on the third set of techniques, 'technologies of power which determine the conduct of individuals and submit them to certain ends or domination, an objectivising of the subject' (Foucault, in Martin et al., 1988, p . 18). The technologies of power are in the heart of the elaboration of govemmentality, a thematic that traverses all of Foucault's later work and turns out to be bound to the last area of practices, the 'technologies of the self, which permit individuals to effect, by their own means, or with the help of others a certain number of operations on their own bodies, and souls, thoughts, conduct and way of being so as to transform themselves, in order to attain a certain state of happiness, purity, wisdom, perfection or immortality' (Foucault , in Martin et al., 1988, p. 18). Governing oneself and governing others are interwoven in the problematics that arise from the exploration of the last two sets of technologies.

The Use of Pleasure and The Care of the Seif are Foucault's only studies about the technologies of the self that were published as books. It is well known that these two books appeared shortly before his death, in 1984, and after Foucault had passed through a long period of contemplation and recollection, which followed the publication of the first volume of his History of Sexuality, in 1976. It was a period during which, Foucault's 'passing' to genealogy was theoretically established. It was moreover 
a period that, as Braidotti has commented, brought forward a new epistemological category: the technology of the subject, 'according to which power produces the real through the processes of normalization that it adopts and the regions of truth it institutes' (Braidotti, 1991, p. 86). It has thus signalled a critical turning point in Foucault's genealogies of the modem subject, by bringing together most rigorously, and in an exemplary way, the three genealogical axes of truth, power and the subject which traverse the whole body of Foucault's analyses. ${ }^{10}$ Apart from his books, however, Foucault 's most 'mature' and elaborated ideas about the writing of genealogies of the subject are dispersed in various essays, lecture transcripts, interviews and course notes. Technologies of the Self (Martin et al., 1988) is a collection of essays, based on the lectures and discussions of the Vermont seminar and it is to these lectures that I now turn.

\section{Technologies of the Self}

Foucault begins his first lecture on technologies of the self by clearly defining sexuality as his dispositij. But what is a dispostif?

Foucault has written that a starting point for 'doing genealogies' should be to focus on a palt.icular problem and then try to see it in its historical dimension; how this problem turned out to be the way we perceive it today. ${ }^{11}$

Dreyfus and Rabinow (1982) point out that in searching for the problem the analyst should identify some socially shared 'discomfort' about how things arc going. Of course there is always the problem that not all social groups can have shared concerns. The perspective of the analyst is decisive in focusing on a particular problem and this should be admitted and used by the analyst in an attempt to deconstruct possible arbitrary personal feelings and stan ces with regard co his/her project. JnNietzsche, Genealogy, History Foucault wrote that genealogy is effective history understood as the 'affirmation of knowledge as perspective' (cited in Simons, 1995, p. 91). As Simons has commented, 'the perspective affirmed is tJ1at of those who resist' (Simons, 1995, p. 91).

Following the first step of isolating the problem, the analyst is tracing the current practices that could relate to the diagnosed 'problem' and finally she or he is trying to folmulate the network of relations between the practices and the problem. Situating the problem in a system of relations that can account for the socially shared discomfort is a turning point for 'doing genealogy' and is immediately related to the Foucauldian methodological concept of dispositif. ${ }^{12}$

As Foucault sees it, a dispositif is a system of relations that can be established between heterogeneous elements, discursive and non-discursive practices, 'the said as well as the un said' (Foucault, in Gordon, 1980, p. 194). A dispositif can include 'discourses, institutions, architectural arrangements, regulations, laws, administrative measures, scientific statements, philosophic propositions, morality, philanthropy, etc.' (Foucault, in Gordon, 1980 , p. 194). There is always 'an urgent need' (Foucault, in Gordon, 1980, p. 195) to which the functioning of the dispositif responds: 'the dispositif is essentially of a strategic nature, which means assuming that it is a matter of a certain manipulation of relations of forces, either developing in a particular direction, blocking them, stabilising them, u tilising them, etc.' (Foucault, in Gordon, I 980, p. 196). Being inscribed in a play of power the dispositif also relates to certain types of knowledge that derive from it, but also condition it. In Foucault's view therefore the analyst has a dispositif when she or he has succeeded in isolating a cluster of power relations sustaining and being sustained by certain types of knowledge (Foucault, in Gordon, 1980, p. 196). 
Deleuze has underlined two important consequences arising from a philosophy of dispositifs: the rejection of universals and a drive away from the Eternal and towards the new. As he has pointed out, in each dispositif it is necessary to distinguish the historical part, what we are (what we arc already no longer) and the current part, what we are in the process of becoming (Dclcuze, in Armstrong, 1992, pp. 163-164).

Following the 'announcement' of his dispositif, Foucault puts together the different elements 'discursive and non discursive' that concerned him in sketching out the diagram of his inquiries. ${ }^{13}$ It is significant that a genealogy should start with a major interrogation of what has been accepted as the 'truth', any truth concerning the ways individuals understand themselves as subjects of this world. The genealogy is thus starting by shattering any certainties, without this questioning being a rhetorical one, asking so as to present pre-existent answers. In posing genealogical questions one can never be sure that one could ultimately find any 'satisfactory answers'. This is the risk, the adventure and the fascination of the exercise.

Foucault places his inquiries on the development of technologies of the self in two different periods: the first two centuries of the Roman empire in the context of problematisations of the Graeco-Roman philosophy, and the fourth and fifth centuries of the late Roman empire, dominated by Christian spirituality. However, he points out that the set of practices under scrutiny in both periods were initially formed as an area of philosophical interest in the classical period. As Foucault explains, these practices were constituted in Greek as epimelesthai sautou, 'to take care of yourself', 'the concern with the self, 'to be concerned, to take care of yourself, which turned out to be one of the main principles of the life of citizens.

Foucault traces the historical development of the 'care for oneself from the Platonic dialogue of Alkibiades, to the period of the Stoics and finally to the era of Christian asceticism. As a genealogist, Foucault works hard to trace the emergence and development of the practices of self-formation. In his discussion of the Platonic thought, he paints the historical as well as the philosophical background of the Socratic dialogues, and starts to weave the nexus of texts, where the care of the self is being analysed in its relation to, as well as its difference and contradictions with, the Delphic principle of gnothi sauton, 'know yourself.

Foucault is careful with minor textual details, scrupulously citing his examples, commenting on their structure, following the 'order of their discourse', comparing and juxtaposing them, tracing their repetition, recurrence or even disappearance in relation lo the era, the philosophical school or even the historical personalities they were adopted by.

In the process of such discussion the 'conclusions' seem to emerge naturally like the subtle drawing of a veil, so easy and simple lo uncover but al the same time so difficult to imagine uncovering. The technologies arc thus revealed, then named, defined and categorised. Despite or perhaps because of his continuous criticism of categorisations, Foucault turns out to be exceptionally effective in forming structures, groups and categories and placing them in an order. His genealogical texts are full of meticulous diagrams, sketches and outlines that systematise the route of his thought and his findings. There arc definitions: 'the theme of the care of the self took the form of an attitude' (Foucault, 1990 , p. 45), subtle discernments: 'pure practices of the self and social practices of care where communication with others is also involved', classifications of self-practices: 'self-examination, speaking and writing about oneself, writing letters, remembering, the an of listening, tlle interpretation of dreams' (Foucault, 1990, pp. 34-35). 
Foucault is careful enough to examine the historical conditions for the emergence of the technologies he is analysing. ${ }^{14} \mathrm{He}$ is also attentive to the chronological ordering of the themes he analyses: 'The examination of conscience begins with this letter writing. Diary comes later' (Foucault, in Martin el al., 1988, p. 30). Foucault is very much interested in the biographical elements of the subjects who practise or are taught how to practise technologies of the self. Thus, he carefully paints Alkibiades' portrait so as to construct his argument about the pedagogical character of the cultivation of the self and its interrelation with both eros or philosophical love and politics: 'During his adolescence Alkibiades was desirable ... but now he wants to dominate others ... he is embarrassed and confused' (Foucault, in Martin et al., 1988, p. 24). The discursive order by which technologies of the self are introduced and developed in philosophical texts is also examined in detail: 'How is this question introduced into the dialogue? (Foucault, in Martin et al., 1988, p. 25).

Keeping his genealogical writings gray, Foucault always systematises hjs otherwise overflowing thought by forming conclusions, tables and groups of notions: This early text ... sets out four main problems to endure throughout antiquity' (Foucault, in Martin el al., 1988, p. 26). He is also weaving systematically the nexus of the power relations, the historical and cultural conditions, and the practices under scrutiny by drawing new lines and making interconnections among the different points of his constructed diagrams: 'In the Hellenistic and imperial periods ..."care of the self' was accepted by Epicurus, ... the Cynics, and by such Stoics as ... The Pythago reans gave attention lo the notion of an ordered life in common' (Foucault, in Martin et al., 1988).

The genealogical analysis finally notes the limits imposed by the social conditions within which practices of the self are cultivated: 'it being understood of course that this phenomenon concerned only the social groups, very limited in number, that were bearers of culture and for whose members a tee/me tau biou could have a meaning and a reality' (Foucault, 1990, p. 45).

A deployn1ent of Foucault's techniques and practices can never be exhaustive or finalised. Foucault's originality lies in his strategic use of different discourses and approaches in the writing of his genealogies. Each reading of these genealogies reveals hidden layers of attentive and detailed research of an immense variety of data. Rather than following methodological principles, Foucault's genealogies create a methodological rhythm of their own, weaving around a set of crucial questions, already introduced in the beginning of this paper. What is happening now? What is this present of ours? How have we become what we are and what are the possibilities of becoming 'other'? Such questions create unexplored and even unthought areas of investigation. Foucault's genealogies do not offer methodological 'certainties'. They persistently evade classification, but they do inspire the writing of new genealogies to interrogate the truths of our world. 


\section{NOTES}

I. Sec Foucault in 'The ethic of care for the self as a practice for freedom', in J. Bernaucr and D. Rasmussen (1988).

2. These theories include the structural linguistics of Ferdinand de Saussure and Emile Benvcniste, Louis Althusser's theory of ideology, the psychoanalysis of Sigmund Freud and Jacques Lacan, Jacques Derrida's theory of 'difference' and Gilles Deleuze's philosophical projec1 of liberating all thinking from its subjection to a univocal image of thought and meaning. The discourses of the crisis of modernity have onl)' recently included a growing number of feminists who arc doing research into theory, politics and subjectivity.

3. As Mahon notes, the key elements of Nietzschean genealogy emerge in opposition to an alternative genealogical approach: that of Paul Ree and the English psychologists with whom Nietzsche associates Rec. For the work of Paul Ree sec in Mahon, 1992, pp. 82, 86, 109, 139

4. Sec Eribon, 1989; Macey, 1993; Miller, 1993.

5. Sec Foucault, 1983

6. Francois Ewald has noted tha1 'genealogy adopts the point of view of the body, that of the tortured, trained, branded, mutilated, decomposed, constrained, subjec1cd body, that of the body which is divided, organised, separated, and reunited' (cited in Mahon, 1992, p. 9). In his influential study Michel Foucault the will to truth, Alan Sheridan has commented extensively on what he calls the 'power-body' conjunction in Foucault, which he sees as directly inherited from Nietzsche (Sheridan, 1990).

7. See Weedon, 1987; Nicholson, 1990; Buttler, 1990, 1993; Sawicki, 1991; McNay, 1992, 1994; Probyn, 1993.

8. 'Our real freedom docs not consist either in 1clling our true s1ories and finding our place within some tradition or ethical code, in completely determining our actions in accordance with universal principles or in accepting our existential limitations in authentic self relation. We are on the contrary "really" free because we can question and modify those systems which make (only) particular kinds of action possible, and because there is no "authentic" self-relation we must conform to' (Rajchman , 1985, p. 122).

9. Without abandoning archaeology, which involved variants of a strict analysis of discourse, Foucault moved beyond the limitations of discourse analysis and became more attentive to that "which conditions, limits and institutionalises discursive formations, namely genealogy.

I 0. Dews (1987) has seen this period a Foucault's 'late return to the subject'. However other thinkers speak of a redefinition of 1 he subject in Foucault through a rejection of certain humanist assumptions about its existence (Simons, 1995, p. 78). What feminist analysts have identified as most problematic about the technologies of subjcct.ivily, however, is that the 'self, Foucault theorises, refers to a desexualised and general 'human subject', where gender difference is simply insignificant. Sec, among others, de Lauretis, 1987; Braidotti, 1991, 1994.

1 1. 'I set out from a problem expressed in the terms current today and I 1ry lo work out its genealogy. Genealogy means that I begin my analysis from a question pod in the present " (Foucault, in Kritman Laurence, 1988, p. 262).

12. Dispositif has been translated in English as 'apparatus' but according lo Dreyfus and Rabinow the term remains excessively vague. With some preoccupations they instead suggest 'grid of intelligibility'. See Dreyfus and Rabinow (1982, p. 120).

13. I asked myself: how had the subject been compelled to decipher himself in regard to what was forbidden? It is a question of the relation between asceticism and truth' (Martin et al., 1988, p. 17).

14. Thus he stresses the way the care of the self was driven in different directions as a result of the disappearance of the city states and the emergence of empires.

\section{REFERENCES}

ARMSTROnG, T. J. (Ed. and Trans.) (1992) Michel Foucault, Philosopher (London, Harvester Wheatsheaf). BERNAUER, J. \& RASMUSSEN, D. (Eds) (1987) The Final Foucault (Cambridge, MA, MIT Press).

BRAJDOTTI, R. (199 1) Patterns of Dissonance (Cambridge, Polity Press).

BRAJDOTTI, R.. (1994) .Nomadic Sui/juts (New York, Columia University Press).

BURCHELl, G., GORDON, C. \& MILLER, P. (Eds) (1991) The Foucault Effect (London, Harvester Wheatsheaf). BUTLER, J.P. (I990) Gender Trouble: feminism and the subversion of (London, Routledge).

BUTLER, J.P. (1993) Bodies that Matter: on the discursive limits of sex (London, Routledge).

DEAN, M. (1994) Critical and Effective Histories (London, Routledge).

DE LAURETIST. (1987) Technologies of gender: essays on theory, film and fiction (London, Macmillan Press). 
DELEUZE, G. (1992) Foucault (Minneapolis, University of Mincssota Press).

DEWS, P. (1987) LOGICS of Disintegration: poststrnctural thought and the claims of critical theory (London, Verso).

DREYFUS, R. \& RABINOW, P. (1982) Michel Foucaul beyond structuralism and hermeneutics (Chicago, Chicago

University Press),

ERIBON, D. (1989) Michel Foucault (London, Faber \& Faber).

FlAX, J. (1990) Thinking Fragmmts: Psychoanalysis, Feminism and Postmodernism in the Contemporary World (Berkeley \& Los Angeles, University of California Press).

FOUCAULT, M. (1970) The Order of Things: an archaeology of human sciences, A. Sheridan (trans.) (London, Tavistock).

FOUCAUlT, M. (1971) Nietzsche, genealogy, history, in: 1Hommage a Jean Hyppolite (Paris, Presses Universitaire de France).

FOUCAUlt, M. (1983) This ls Not a Pipe (Berkeley, University of California Press).

FOUCAUiT, M. (1990) Thee Care of the Self, History of Sexuality, Vol. 3 (London, Penguin).

FOUCAUl.T, M. (1991) Disciplilu and Punish (London, Penguin).

GORDON C. (ED.) (1980) Power/Knowldge: selected inyerviews and other writings 1972-1977 (London, Harvester Wheatsheaf).

KRITZMAN, L. D. (ED.) (1988) Michel Foucault, Politics PhiLOSOPHY, Culture (London, Routledge). L

MACEY, D. (1993) The Lives of Michel Foucault (London, Hutchinson).

MAGGIL, K. (1997) Surveillance-free-subjects, in: M. Lloyd \& A.Thacker (Eels) The Impact of Michel Foucault on the Social Scimces and Humanities (London, McMillan Press).

MAJON, M. (1992) Foucault's Nietzschean Genalogy: Truth, Power and the Subject (Albany, New York Slate University Press).

MARTIN, L. GUTMAN H. \& HUTTON P. (Eds) (1988) Technologies of the Self. (London, Tavistock).

MCNAY, L. (1992) Foucault and Feminism (Cambridge, Polity Press).

MCNAY, L. (1994) Foucault: a critical introduction (Cambridge, Polity Press).

MAY, T. (1993) Between Genealogy and Epistemology: psychology, politics and knowledge in the thought of Michel Foucault (Pittsburgh, PA, Pennsylvania State University Press).

MILLER, J. (1993) The Passion of Michel Foucault (London, Harper Collins),

NICHOLSON, L. (Ed.) (1990) Feminism/Postmodemism (London, Routledge).

PROBYN, E. (1993) Sexing the Self: positions in cultural studies (London, Routledge).

RARINOW, P. (Ed.) (1986) TI1t Fourault Render (London, Peregrine).

RAJCHMAN,J. (1985) Michel Foucault and the Freedom of Philosophy (New York, Columbia University Press).

RAJCHMAN, J. (1986\} Ethics after Foucault, Social Te.-t, Spring, pp. 165-183.

RAJClIMAN, J. (1991) Trnth and Eros: Foucault, Lacan and the question of ethics (London, Routledge).

SAWICKI, J. (1991) Disciplining Foucault (London, Routledge).

SHERIDAN, A. (1990) Michel Foucault the will to truth (London, Routledge).

SIMONS, J. (1995) Foucault and the Polilical (London, Routledge).

VEYNE P. (1997) Foucault revolutionalises history, in: A.I. Davidson (Ed.) Foucaull and his Interlocutors (Chicago, University of Chicago Press).

WEEDON, C. (1987) Femin ist Practice and Postructuralist Theory (New York, Basil Blackwell).

YOUNG, R. (Ed.) (1981) Untying the Text: a post-structuralist reader (Boston, Routledge \& Kegan Paul). 